\title{
PENGARUH KEGIATAN BERCERITA DENGAN BUKU CERITA ISLAMI TERHADAP PERILAKU MORAL ANAK
}

\author{
Meryl Dwi Susanti \\ e-mail: meryl.memey@yahoo.com \\ PG PAUD FIP Universitas Negeri Jakarta
}

\begin{abstract}
Abstrak: Penelitian ini bertujuan untuk memperoleh data empiris tentang pengaruh kegiatan bercerita dengan buku cerita Islami terhadap perilaku moral anak usia 5-6 tahun di RA Unwanul Khairiyah dan RA Nurul Akbar. Penelitian dilaksanakan pada semester I tahun pelajaran 2012-2013, yakni pada bulan OktoberDesember 2012. Metode penelitian yang digunakan adalah Expost Facto. Sampel penelitian adalah anak usia 5-6 tahun di RA Unwanul Khairiyah dan RA Nurul Akbar, masing-masing sebanyak 20 siswa dengan teknik pengambilan sample yaitu simple random sampling. Teknik analisis data terlebih dahulu dilakukan dengan uji persyaratan yang terdiri dari normalitas dan homogenitas. Penelitian ini menyimpulkan, terdapat pengaruh positif signifikan kegiatan bercerita dengan buku cerita Islami terhadap perilaku moral anak usia 5-6 tahun. Implikasi hasil penelitian adalah guru sebaiknya menciptakan kegiatan yang dapat dijadikan pembelajaran dalam menanamkan perilaku moral kepada anak sesuai usianya dengan cara menyenangkan, salah satunya kegiatan bercerita dengan buku cerita Islami. Guru juga perlu lebih kreatif dalam menggunakan metode dan media. Kegiatan bercerita dengan buku cerita Islami dapat dijadikan sarana untuk menanamkan anak menjadi individu yang berperilaku baik.
\end{abstract}

Kata Kunci : kegiatan bercerita, buku cerita islami, perilaku moral

\section{EFFECTS OF STORY TELLYING WITH ISLAMIC BOOKS ON CHILDREN'S MORAL BEHAVIOR}

\begin{abstract}
This study aims to obtain empirical data on the effects of storytelling activities with Islamic books on moral behavior of the children aged 5-6 years in Unwanul Khairiyah RA and RA Nurul Akbar. The research method used was ex post facto. The research samples were 20 children selected by simple random sampling. The techniques of data analysis conducted prior to the test requirements consisted of normality and homogeneity. This study concluded that there are significant positive storytelling activities with Islamic books on moral behavior of the children aged 5-6 years. The implications of the results of the study are that teachers should create learning activities that can develop the children's moral behavior in a joyful method such as story telling with Islamic books. The teachers also need to be more creative in using methods and media.
\end{abstract}

Keywords: story telling, Islamic book, moral behavior

\section{PENDAHULUAN}

\section{Latar Belakang}

Sedari dini anak perlu diajarkan mengenai perilaku baik dan tidak baik, hal ini bertujuan agar anak dapat menjadi pribadi yang baik bagi diri sendiri, lingkungan dan agama. Tiga aspek tersebut akan membuat anak menjadi pribadi yang mudah bersosialisasi dan diterima serta disenangi di lingkungan. Memberikan pembelajaran baik dan yang tidak baik merupakan pembelajaran dasar untuk menanamkan perilaku moral kepada anak. Perilaku moral merupakan perilaku yang harus dimiliki oleh setiap orang tak terkecuali anak usia dini.

Usia pra sekolah adalah dimana anak masih mu- dah terbawa arus dan mudah terpengaruh lingkungan sekitarnya. Mereka sangat membutuhkan bimbingan, proses latihan, serta pembiasaan yang terus-menerus. Maka seorang guru diharapkan dapat memberikan berbagai macam kegiatan dalam pembelajaran di sekolah yang dapat menanamkan perilaku moral kepada anak. Faktor eksternal yang telah dijelaskan akan mempengaruhi perilaku moral pada seorang anak. Moshos dan Nancy berpendapat bahwa perilaku moral usia 5 hingga 6 tahun : (1) anak sudah memperhatikan peraturan lebih serius dari usia sebelumnya namun belum sepenuhnya diinternalisasikan mereka, (2) anak memiliki bakat mengembangkan hati nurani, 
(3) anak masih mendefinisikan tindakan sebagai benar atau salah terutama kepada orang tua dan guru untuk menghindari hukuman (Moshos \& Scoott, 2005:13-14). Indikator perilaku tersebut diharapkan dapat diterapkan dan dikembangkan dalam proses pembelajaran secara keseluruhan.

Salah satu pembelajaran untuk menerapkannya yaitu dengan kegiatan bercerita dengan buku cerita Islami. Kegiatan bercerita dengan buku cerita Islami merupakan salah satu kegiatan yang dapat diberikan oleh guru kepada anak usia pra sekolah. Kegiatan bercerita dengan buku cerita Islami akan memiliki daya tarik tersendiri untuk anak apabila guru sebagai orang yang memberikan cerita mampu menyiapkan serta menyampaikannya dengan baik. Namun apa yang diharapkan tidak sesuai dengan kenyataan yang ada di lapangan.

Kenyataannya di lapangan guru saat ini jarang memberikan kegiatan bercerita. Ini dikarenakan saat ini guru lebih banyak memberikan kegiatan pembelajaran yang berfokus pada pengembangan aspek akademik anak seperti kegiatan calistung. Padahal masa usia pra sekolah merupakan masa-masa anak aktif dalam berimjinasi (Musfiroh, 2008:83). Hal ini menunjukkan bahwa imajinasi anak-anak tidak disalurkan dengan baik oleh guru melalui kegiatan bercerita. Ketidak ahliannya guru dalam menyajikan cerita merupakan salah satu penyebab yang terjadi saat ini kegiatan bercerita kurang diberikan kepada anak.

Selain hal yang telah dipaparkan di atas, media elektronik seperti televisi juga dapat memberikan pengaruh dalam berperilaku anak. Televisi dapat memberikan pengaruh yang positif untuk anak. Kenyataan yang ada saat ini membuktikan pengaruh buruk yang mucul dari berbagai sumber sering dijumpai anak seperti penayangan televisi, film, vidio, permainan, musik, bahkan iklan memberikan pengaruh buruk bagi moral anak karena menyodorkan sinisme, pelecehan, materialisme, seks bebas, kekasaran, dan pengagungan kekerasan (Borba, 2008:5). Adanya pengaruh negatif tersebut menyebabkan anak pada saat usia memasuki remaja sudah melakukan perilaku yang tidak bermoral, seperti seks bebas dan berujung dengan pernikahan dini bahkan aborsi.

Hal yang telah disebutkan di atas diperkuat oleh data survei Komnas Perlindungan Anak tahun 2010 mengungkapkan bahwa $97 \%$ remaja pernah menonton atau mengakses materi pornografi, $93 \%$ remaja pernah berciuman, $62,7 \%$ remaja pernah berhubungan badan dan $21 \%$ remaja Indonesia telah melakukan aborsi (Tri Suyatno, 2011:2). Hal tersebut terjadi dikarenakan kurangnya pengetahuan dan pemahaman tentang moral. Berdasarkan kenyataan yang dijelaskan, dapat disimpulkan bahwa guru kurang memberikan kegiatan bercerita sebagai salah satu kegiatan pembelajaran untuk anak. Selain itu kurangnya penanaman perilaku moral anak sejak dini dari guru selaku orang tua anak disekolah menjadi salah satu pemicu anak pada saat ini berperilaku yang tidak baik, karena sebagian waktu anak dihabiskan di luar rumah yaitu sekolah.

\section{Rumusan Masalah}

Melihat harapan dan kenyataan serta kesenjangan yang yang terjadi di lapangan, peneliti tertarik untuk meneliti apakah terdapat pengaruh kegiatan bercerita dengan buku cerita Islami terhadap perilaku moral anak usia 5-6 tahun. Peneliti tertarik untuk melakukan penelitian ini di RA Unwanul Khairiyah, Depok. Hal ini dikarenakan Uhwanul Khairiyah merupakan RA yang sudah memberikan kegiatan bercerita dengan buku Islami terhadap anak usia 5-6 tahun .

\section{Kajian Teori}

\section{a. Perilaku Moral}

Perilaku merupakan cara dimana seorang individu berperilaku atau bertindak (UNESCO, 2000:9). Hal tersebut sesuai dengan pendapat Martin dan Pear behavior is anything that a person says or does (JB. Waston, 1999:15). Bahwa perilaku adalah apapun yang dikatakan atau dilakukan oleh seseorang. Dengan kata lain perilaku akan terjadi apabila ada sesuatu yang diperlukan untuk menimbulkan reaksi atau disebut rangsangan. Rangsangan tertentu akan menghasilakan reaksi atau perilaku tertentu.

Moral adalah suatu keyakinan tentang benar salah, baik buruk, yang sesuai dengan kesepakatan sosial yang mendasari tindakan atau pemikiran. Atkinson dalam Sjarkawi mengemukakan moral merupakan pandangan tentang baik dan buruk, benar dan salah, apa yang dapat dan tidak dapat dilakukan (Sjarkawi, 2006:28). Hal diatas menjelaskan bahwa moral bukan hanya suatu kepatuhan belaka terhadap suatu aturan melainkan adanya pemahaman dan terlibatnya pikiran, perasaan atas baik dan buruk, benar maupun salah.

Perilaku moral berarti perilaku yang sesuai dengan kode moral kelompok sosial. Perilaku moral dikendalikan konsep-konsep moral - peraturan perilaku yang telah menjadi kebiasaan bagi anggota suatu budaya dan yang menentukan pola perilaku yang diharapkan dari seluruh anggota masyarakat (Hurlock, 1999:74). Perilaku manusia yang tidak sesuai dengan harapan sosial atau masyarakat berarti manusia tersebut tidak bermoral. Berdasarkan pengertian perilaku moral yang telah diuraikan,peneliti mendeskripsikan bahwa perilaku moral adalah suatu tindakan seseorang yang sesuai dengan aturan yang dianggap baik oleh 
kontek sosial, budaya dan nilai-nilai yang ada di masyarakat.

Anak usia dini memiliki karakteristik yang berbeda-beda dalam rentang usianya. Seoarang anak tentunya juga memiliki karakteristik perkembangan moralnya sendiri. Pada usia ini anak sudah mulai mencerna kaidah moral. Perilaku usia 5 hingga 6 tahun anak memperhatikan peraturan lebih daripada sebelumnya, tetapi belum sepenuhnya diinternalisasi oleh anak. Anak memiliki bakat untuk mengembangakan hati nurani. Anak masih mendefinisikan tindakan sebagai benar atau salah terutama kepada orang tua dan guru untuk menghindari hukuman. Anak masih memiliki jalan panjang untuk menuju ke kedewasaan moral (Moshos \& Scoott, 2005:13).

\section{b. Kegiatan Bercerita}

Kegiatan adalah sesuatu yang dilakukan oleh seseorang. Kegiatan merupakan satu aktivitas yang dilakukan dengan tujuan tertentu (Salim, 1997:475). Bercerita adalah salah satu kegiatan yang memiliki tujuan untuk diberikan kepada siapa saja, baik untuk anak-anak ataupun orang dewasa. Hal ini sesuai dengan pendapat Mal bahwa bercerita adalah suatu seni dalam menyampaikan ilmu, pesan, nasihat kepada orang lain baik anak-anak, remaja, dewasa maupun orang tua (Mal,, 2008:3). Hal ini menjelaskan bahwa kegiatan bercerita merupakan kegiatan yang bertujuan memberikan pembelajaran kepada semua umur.

Bercerita merupakan salah satu pemberian pengalaman belajar bagi anak TK dengan membawakan cerita kepada anak secara lisan (Moeslichatoen, 2004:157). Pemberian pengalaman pembelajaran kepada anak dalam bercerita dapat berupa informasi ataupun pesan-pesan yang mengandung nilai moral. Ini sependapat dengan Gunarti bahwa kegiatan bercerita merupakan kegiatan yang dilakukan seseorang untuk menyampaikan suatu pesan, informasi atau sebuah dongeng belaka, yang biasa dilakukan secara lisan atau tertulis (Gunarti, 2010:5.3). Kegiatan bercerita merupakan kegiatan yang dilakukan secara lisan ataupun tertulis guna menyampaikan suatu pesan kepada anak.

Pada dasarnya untuk melakukan kegiatan bercerita secara menarik diperlukan beberapa persiapan mulai dari mengkondisikan anak, menentukan tempat, menyiapkan alat peraga hingga penyajian cerita. Adapun langkah bercerita yang dilakukan, yaitu (1) mengkomunikasikan tujuan dan tema dalam kegiatan bercerita kepada anak (2) mengatur tempat duduk anak (3) pembukaan kegiatan bercerita (4) pengembangan cerita yang dituturkan guru (5) penutup kegiatan bercerita (Moeslichatoen, 2004:179). Langkah-langkah tersebut perlu diperhatikan dalam kegiatan bercerita untuk anak, agar tujuan kegiatan bercerita dapat disampaikan dan diterima baik oleh anak.

Kegiatan bercerita dapat digunakan untuk mengembangkan perilaku dan kemampuan dasar anak usia dini. Hal ini sesuai dengan pendapat Mal bahwa tujuan bercerita yaitu menyampaikan pesanpesan moral tanpa berkesan menggurui atau memaksakan pendapat (Mal, 2008:3). Ini membuktikan bahwa pesan-pesan yang dituturkan melalui kegiatan bercerita efektif untuk mempengaruhi cara berfikir anak sehingga dapat membentuk pribadi dan moral anak. Selain itu kegiatan bercerita memiliki manfaat untuk anak sebagai pengalaman belajar untuk berlatih mendengarkan (Moeslichatoen, 2004:168). Melalui mendengarkan anak akan memperoleh bermacam informasi tentang pengetahuan, nilai, dan sikap untuk dihayati dan diterapkan dalam kehidupan sehari-hari.

Banyak jenis cerita yang dapat disampaikan kepada anak, namun jenis cerita yang menarik untuk anak tentu berlainan, ini tergantung pada pemahaman dan pengalaman yang didapat anak sebelumnya. Salah satu jenis cerita yaitu cerita Islami dikenal dengan sebutan kisah, yaitu sejenis cerita yang penyampaiannya berasal dari Al-Qur'an dan kisah teladan lain yang dibaur (Handayu, 2001:116). Hal ini dapat diuraikan bahwa cerita Islami merupakan kisah-kisah yang tertulis dalam Al-Quran, serta kisah lain yang memiliki nilai keteladanan. Cerita keteladanan yang dimaksud adalah cerita yang didalamnya banyak tersirat nilai-nilai kebaikan dan moral ajaran islam serta dapat dijadikan teladan oleh anak, sehingga anak dapat mengetahui mana yang baik dan mana yang buruk.

Cerita Islami merangsang minat anak usia dini. Hal ini dikarenakan isi dari cerita Islami dapat menyentuh perasaan anak, sehingga kesan yang disampaikan dalam cerita Islami akan diingat oleh anak dan menggerakkan anak untuk meneladani cerita islami. Syantut berpendapat bahwa kisah-kisah para nabi memuat nilai-nilai akhlak yang terpuji (Syantut, 2005:63). Cerita Islami menanamkan nilai-nilai yang disukai anak. Sebagaimana fitrahnya, anak usia dini masih mempunyai pemikiran yang bersih, hati yang suci, dan cenderung berpihak pada hal-hal yang baik.

Selain itu, Wahyudi dan Damayanti mengemukakan bahwa cerita sahabat nabi dan para teladan Islam tidak hanya menampilkan kronologi peristiwa sejarah semata, tetapi membawa pesan-pesan moral dan etika (Wahyudi \& Damayanti, 2005:9). Isi cerita Islami banyak terkandung nilai-nilai empati, toleransi dan tertanam dalam diri anak. Selain itu, nilai-nilai kebaikan yang tersirat dalam cerita Islami juga sangat 
jelas, sehingga anak akan mengenal baik dan buruk secara kongkret. Berdasarkan penjelasan yang telah dipaparkan, maka dapat disimpulkan bahwa terdapat banyak jenis cerita untuk anak dengan kategori yang bermacam-macam. Jenis-jenis cerita tersebut memiliki isi dan keunggulannya masing-masing., segala jenis cerita akan tetap menarik bagi anak apabila guru dapat menyampaikan cerita sesuai dengan perkembangan anak.

\section{METODE PENELITIAN}

Secara umum penelitian ini bertujuan untuk memperoleh data empiris tentang pengaruh pemberian kegiatan bercerita dengan buku cerita islami terhadap perilaku moral anak usia 5-6 tahun di RA Unwanul Khairiyah dan RA Nurul Akbar, Depok. Penelitian ini dilaksanakan di RA Unwanul Khairiyah dan RA Nurul Akbar, Depok. Penentuan waktu penelitian ini disesuaikan dengan variabel yang akan diteliti dan teknik pengambilan sampel. Hal ini dimaksudkan agar tujuan penelitian dapat tercapai.Penelitian dilaksanakan pada semester I tahun pelajaran 2012-2013, yakni pada bulan Oktober-Desember 2012. Metode yang digunakan dalam penelitian ini adalah metode expost facto.

Penelitian ini tidak mengadakan/memberikan perlakuan terhadap variabel yang diteliti, melainkan hanya memeriksa efekperlakuan yang sudah berlangsung secara alami. Metode penelitian ini menggunakan dua kelompok yaitu perilaku moral anak kelompok pemberian kegiatan bercerita dengan buku cerita Islami dan perilaku moral anak kelompok tidak ada pemberian kegiatan bercerita Islami. Kelompok pertama terdiri dari 20 orang dan kelompok kedua terdiri dari 20 orang. Kedua kelompok masing-masing dihubungkan antara variabel $x$ dan variabel $y$. Hasil tersebut kemudian dianalisa untuk dilakukan uji hipotesis.

Populasi dalam penelitian ini adalah seluruh murid RA dengan usia 5-6 tahun yang berada diwilayah Kelurahan Kemiri Muka, meliputi RA AI Qudwah, RA Assalam, RA Bina Mujtama, RA Nurul Akbar, RA Unwanul Khairiah. Sekolah tersebut masuk dalam populasi karena mempunyai kesamaan status sekolah yaitu sekolah RA dengan waktu sekolah di pagi hari dan kesamaan dalam kurikulum. Sampel penelitian yang digunakan dalam penelitian ini ditentukan dengan menggunakan teknik simple random sampling pengambilan sampel dilakukan dengan cara undian. Setelah dilakukan secara acak dengan undian, maka sampel yang terpilih dalam penelitian ini adalah murid RA Unwanul Khairiyah dan RA Nurul Akbar yang berusia 5-6 tahun.

Variabel merupakan sesuatu yang harus ada dalam sebuah penelitian. Variabel dalam penelitian ini terbagi menjadi dua, yaitu variabel terikat dan variabel bebas. Variabel bebas atau variabel $\mathrm{X}$ dalam penelitian ini yaitu kegiatan bercerita dengan buku cerita Islami, sedangkan perilaku moral anak sebagai variabel terikat atau variabel $Y$. Variabel yang akan diteliti oleh peneliti adalah perilaku moral anak usia 5-6 tahun.

Teknik pengumpulan data yang digunakan untuk mendapatkan data mengenai variabel kegiatan bercerita adalah dengan menggunakan wawancara kepada guru seputar kegiatan bercerita yang biasa dilakukan disekolah, sedangkan untuk variabel perilaku moral menggunakan angket non tes yaitu observasi dan kuesioner. Untuk memperoleh data pada variabel perilaku moral anak dilakukan observasi selama 20 hari berturut-turut menggunakan lembar observasi dan angket. Angket yang digunakan adalah model tertertutup yang sudah disediakan jawabannya dan responden tinggal memilih jawaban yang sudah ada. Angket yang dibuat peneliti sesuai dengan kisi-kisi yang disusun berdasarkan definisi operasional dengan indikator dan karakteristik yang terkandung dalam teori-teori yang berisi pertanyaan-pertanyaan tentang perilaku moral anak usia 5-6 tahun.

Instrumen yang akan digunakan dalam penelitian ini perlu diukur tingkat validitas dan reabilitasnya agar data yang dihasilkan benar-benar valid dan reliable. Pengujian validitas dalam penelitian ini dilakukan melalui dua tahap yaitu pengujian validitas secara teoritik dan empirik. Secara teoritik, pengujian validitas instrumen ini dinilai berdasarkan indikator dari variabel penelitian yang kemudian dikonsultasikan atau dilakukan pemeriksaan oleh para ahli atau peneliti (expert judgement) yang didalamnya termasuk dosen pembimbing skripsi. Selanjutnya dilakukan secara empirik, yaitu dengan menguji instrumen di lapangan Instrumen tersebut disebar kepada respondenresponden dan harus diketahui validitas dan realibilitasnya terlebih dahulu. Instrument di uji validitas dan realibilitasnya pada waktu dan tempat yang berbeda. Uji coba pada instrumen ini dilakukan pada anak TK B di TK Islam AT-Taqwa tahun ajaran 2012-2013. Uji coba dilakukan terhadap 30 anak yang memiliki kriteria 5-6 tahun. Instrumen yang telah disebar kelapangan kemudian di uji coba dengan menganalisis butir instrumen dan membandingkan rhitung dengan $r_{\text {tabel }}$. Rumus yang digunakan untuk menguji tingkat validitas dalam 
penelitian ini adalah rumus kolerasi product moment.

Dari hasil perhitungan uji validitas untuk instrumen perilaku moral anak usia 5-6 tahun diperoleh skor $r_{\text {hitung }}$ adalah 0,787 sedangkan nilai $r_{\text {tabel }}$ pada taraf signifikan $\propto=0,05$ dan $\mathrm{n}=30$ adalah 0,360 maka $r_{\text {hitung }}(0,787)>r_{\text {tabel }}(0,360)$, berarti instrumen tersebut dinyatakan valid dan layak digunakan untuk penelitian selanjutnya. Setelah melakukan uji validitas, intrumen kemudian di uji kembali yaitu dengan uji reliabilitas instrumen pada penelitian ini adalah rumus Alpha Cronbach', hal ini bertujuan untuk instrumen dikatakan reliabel bila digunakan untuk mengukur suatu aspek beberapa kali, hasilnya sama atau relatif sama. Instrumen yang reliabel akan menghasilakan data dapat dipercaya

\section{HASIL DAN PEMBAHASAN}

\section{Hasil Penelitian}

Data yang dianalisis dalam penelitian ini adalah tentang perilaku moral anak usia 5-6 tahun. Data ini diperoleh dari hasil observasi kedua sekolah yang menggunakan pembelajaran kegiatan bercerita dengan buku cerita Islami maupun sekolah yang tidak menggunakan pembelajaran kegiatan bercerita dengan buku cerita Islami. Data dari hasil penelitian dideskripsikan untuk memperoleh gambaran tentang karakteristik distribusi nilai dan variabel penelitian. Deskripsi data penyajian nilai tertinggi, nilai terendah, rerata, standar deviasi, modus dan median. Deskripsi data juga disajikan dalam bentuk tabel distribusi frekuensi dan histogram. a. Hasil Perilaku Moral Anak yang Menggunakan Kegiatan Bercerita dengan Buku Cerita Islami (Kelompok 1)

Tabel 1. Perilaku Moral Anak Yang Menggunakan Kegiatan Bercerita Dengan Buku Cerita Islami

\begin{tabular}{|c|c|c|c|c|}
\hline $\begin{array}{c}\text { Kelas } \\
\text { Interval }\end{array}$ & $\begin{array}{c}\text { Batas } \\
\text { bawah }\end{array}$ & Batas atas & $\begin{array}{c}\text { Frek. } \\
\text { Absolut }\end{array}$ & $\begin{array}{c}\text { Frek. } \\
\text { Relatif }\end{array}$ \\
\hline $44-45$ & 43,5 & 45,5 & 1 & $5 \%$ \\
\hline $46-47$ & 45,5 & 47,5 & 2 & $10 \%$ \\
\hline $48-49$ & 47,5 & 49,5 & 8 & $40 \%$ \\
\hline $50-51$ & 49,5 & 51,5 & 4 & $20 \%$ \\
\hline $52-53$ & 51,5 & 53,5 & 2 & $10 \%$ \\
\hline $54-55$ & 53,5 & 55,5 & 3 & $15 \%$ \\
\hline & & & 20 & $100,00 \%$ \\
\hline
\end{tabular}

Jumlah responden dalam penelitian ini adalah 20 anak dengan nilai yang diperoleh dari penelitian untuk kelompok perilaku moral anak yang menggunakan kegiatan bercerita dengan buku cerita Islami, yaitu dari 20 anak didapat nilai tertinggi dengan skor 55 dengan jumlah butir instrumen 14, dari 20 anak didapat nilai terendah yaitu dengan skor 45 dengan jumlah butir isntrumen 14; dari 20 anak didapat rata-rata nilai anak yaitu 49,9 dengan jumlah butir instrumen 14; dari 20 anak didapat nilai median atau nilai tengah yaitu 49; dari 20 anak didapat nilai modus atau nilai yang paling sering muncul yaitu 49 dan berdasarkan perhitungan didapat nilai varians 7,989; serta standar deviasi 2,827.

Berdasarkan data pada tabel 1, dapat diperoleh nilai frekuensi dan nilai nyata interval dari masingmasing kelompok interval. Jumlah responden yang berada di bawah skor rata-rata adalah 3 dari 20 responden (anak) atau jika dipersentasikan sebesar $15 \%$ anak yang mendapat skor di bawah rata-rata dari $100 \%$, dari 20 responden (anak) jumlah anak yang berada di kelas rerata yaitu terdapat 8 atau bila dipersentasikan sebesar $40 \%$ anak yang berada di kelas rerata dari $100 \%$ dan kelas yang berada di atas rata-rata yaitu 9 dari jumlah 20 responden (anak) atau bila dipersentasikan sebesar $45 \%$ anak yang berada diatas rata-rata dari $100 \%$.

b. Hasil Perilaku Moral Anak yang Tidak Menggunakan Kegiatan Bercerita dengan Buku Cerita Islami (Kelompok 2)

Tabel 2. Perilaku Moral Anak Yang Tidak Menggunakan Kegiatan Bercerita Dengan Buku Cerita Islami

\begin{tabular}{|c|c|c|c|c|}
\hline $\begin{array}{c}\text { Kelas } \\
\text { Interval }\end{array}$ & $\begin{array}{c}\text { Batas } \\
\text { bawah }\end{array}$ & Batas atas & $\begin{array}{c}\text { Frek. } \\
\text { Absolut }\end{array}$ & $\begin{array}{c}\text { Frek. } \\
\text { Relatif }\end{array}$ \\
\hline $36-38$ & 35,3 & 38,5 & 3 & $15 \%$ \\
\hline $39-41$ & 38,5 & 41,5 & 8 & $40 \%$ \\
\hline $42-44$ & 41,5 & 44,5 & 2 & $10 \%$ \\
\hline $45-47$ & 44,5 & 47,5 & 2 & $10 \%$ \\
\hline $48-50$ & 47,5 & 50,5 & 1 & $5 \%$ \\
\hline $51-53$ & 50,5 & 53,5 & 4 & $20 \%$ \\
\hline & & & & $100,00 \%$ \\
\hline
\end{tabular}

Jumlah responden dalam penelitian ini adalah 20 anak dengan nilai yang diperoleh dari penelitian untuk kelompok perilaku moral anak yang tidak menggunakan kegiatan bercerita dengan buku cerita Islami yaitu didapat nilai tertinggi dari 20 responden (anak) dengan skor 53 dengan jumlah butir instrumen 14, dari 20 anak didapat nilai terendah yaitu dengan skor 36 dengan jumlah butir isntrumen 14; dari 20 anak didapat rata-rata nilai anak yaitu 43,2 dengan jumlah 
butir instrumen 14; dari 20 anak didapat nilai median atau nilai tengah yaitu 40,5; dari 20 anak didapat nilai modus atau nilai atau skor yang paling banyak yaitu 40 dan berdasarkan perhitungan didapat nilai varians 30,379; serta standar deviasi 5,512.

Berdasarkan tabel 2, dapat diperoleh nilai frekuensi dan nilai nyata interval dari masing-masing kelompok interval. Jumlah responden yang berada di bawah skor rata-rata adalah 11 dari 20 responden (anak) atau jika dipersentasikan sebesar 55\% anak yang mendapat skor dibawah rata-rata dari 100\%, dari 20 responden (anak) jumlah anak yang berada di kelas rerata yaitu terdapat 2 atau bila dipersentasikan sebesar $10 \%$ anak yang berada di kelas rerata dari $100 \%$ dan kelas yang berada di atas rata-rata yaitu 7 dari jumlah 20 responden (anak) atau bila dipersentasikan sebesar $35 \%$ anak yang berada diatas rata-rata dari $100 \%$.

Pengujian normalitas variabel dilakukan dengan tujuan untuk mengetahui apakah sampel berdistribusi normal atau tidak. Jika sebaran data berdistribusi normal maka penelitian ini termasuk ke dalam statistik parametik. Sampel dikatakan tersebar dalam distribusi normal jika harga Lhitung lebih kecil dari harga Ltabel dan sebaliknya jika harga Lhitung lebih besar dari harga Ltabelmaka data yang diperoleh tidak berdistribusi normal. Pengujian ini dilakukan dengan menggunakan Uji Lilifors.

a. Uji Normalitas Data Perilaku Moral Anak Usia 5-6

Tahun yang Menggunakan Kegiatan Bercerita dengan Buku Cerita Islami (kelompok 1)

Berdasarkan hasil penelitian dengan Uji Lilifors didapat Lhitung Kelompok I sebesar 0,164. Ltabel pada taraf signifikansi, $\alpha=0,05 n=20$ adalah sebesar 0,190 jadi Lhitung $=(0,164)$ dan Ltabel $=(0,190)$ artinya sebaran data Kelompok 1 berdistribusi normal, dikatakan normal karena berdasarkan perhitungan yang dilakukan oleh peneliti sesuai dengan data, didapat hasil bahwa Lhitung $(0,164)$ lebih kecil hasilnya dari Ltabel $=(0,190)$.

b. Uji Normalitas Data Perilaku Moral Anak Usia 5-6

Tahun yang Tidak Menggunakan Kegiatan Bercerita dengan Buku Cerita Islami (kelompok 2)

Berdasarkan hasil penelitian dengan Uji Lilifors didapat Lhitung Kelompok I sebesar 0,173. Ltabel pada taraf signifikansi, $\alpha=0,05 n=20$ adalah sebesar 0,190 jadi Lhitung $=(0,173)$ dan Ltabel $=(0,190)$ artinya sebaran data Kelompok 2 berdistribusi normal, dikatakan normal karena berdasarkan perhitungan yang dilakukan oleh peneliti sesuai dengan data, didapat hasil bahwa Lhitung $(0,173)$ lebih kecil hasilnya dari Ltabel $=(0,190)$.
Uji homogenitas dilakukan dengan Uji Bartlett yaitu uji kesamaan varians antara kelompok 1 dan kelompok 2. Pengujian ini menggunakan kriteria pengujian sebagai berikut : pertama membuat pengelompokkan data kelompok 1 dan kelompok 2, menghitung nilai-nilai $\mathrm{db}, \mathrm{I} / \mathrm{db}, \mathrm{S} 1^{2}, \log \mathrm{S} 1^{2}$, dan $\mathrm{db}\left(\mathrm{S} 1^{2}\right)$ selannjutnya nilai-nilai tersebut dihitung $\mathrm{Y}^{2}$ dan hasil disebut $Y^{2}$ hitung . Hal tersebut dapat dikatakan varians kelompok 1 dengan kelompok 2 homogen dimana $Y^{2}$ hitung $<Y^{2}$ tabel pada taraf signifikansi $\alpha=0,05 n=$ 40 adalah sebesar 3,84.

Berdasarkan perhitungan yang dilakukan peneliti, kelompok 1 dan 2 diperoleh $Y^{2}$ hitung $=0,150$ dan $Y^{2}$ tabel $=3,84$; jadi $Y^{2}$ hitung $(0,150)<Y^{2}$ tabel $(3,84)$ artinya sebaran data kelompok 1 dan kelompok 2 mempunyai varians yang homogen, dikatakan homogen karena berdasarkan perhitungan yang telah dilakukan sesuai dengan data, didapat hasil $Y^{2}$ hitung lebih kecil dari $Y^{2}$ tabel.

Hipotesis yang diuji adalah terdapat pengaruh yang positif signifikan antara penggunaan kegiatan bercerita dengan buku cerita Islami dengan perilaku moral anak usia 5-6 tahun di RA kelompok B. Pengujian hipotesis menggunakan rumus uji t. Statistik uji $\mathrm{t}$ dilakukan untuk menguji hipotesis nol $(\mathrm{H} 0)$ apakah diterima yang berarti tidak terdapat pengaruh yang signifikan kegiatan bercerita dengan buku cerita Islami terhadap perilaku moral anak usia 5-6 tahun. Apakah (H0) ditolak yang berarti terdapat pengaruh yang signifikan kegiatan bercerita dengan buku cerita Islami terhadap perilaku moral anak usia 5-6 tahun.

Berdasarkan hasil analisis yang menggunakan rumus uji t diperoleh bahwa thitung $=4,837$ dan ttabel pada taraf signifikansi $\alpha=0,05$ dengan $n=40$ adalah 1,68 dengan demikian $\mathrm{HO}$ yang menyatakan tidak terdapat pengaruh yang positif signifikan kegiatan bercerita dengan buku cerita Islami terhadap perilaku moral anak ditolak dan $\mathrm{H} 1$ yang menyatakan bahwa terdapat pengaruh positif signifikan kegiatan bercerita dengan buku cerita Islami terhadap perilaku moral anak diterima. Berdasarkan hasil pengujian hipotesis tersebut, maka dapat disimpulkan bahwa terdapat pengaruh yang positif signifikan kegiatan bercerita dengan buku cerita Islami terhadap perilaku moral anak usia 5-6 tahun.

\section{Pembahasan}

Perilaku moral anak yang menggunakan kegiatan bercerita dengan buku cerita Islami lebih baik dibandingkan dengan anak yang tidak menggunakan kegiatan bercerita dengan buku cerita Islami, sehingga pembelajaran dengan kegiatan bercerita dengan buku cerita Islami berdampak positif terhadap perilaku moral 
anak usia 5-6 tahun. Untuk melihat perilaku moral anak dalam penelitian ini dilakukan dengan mengobservasi perilaku anak setiap hari selama kegiatan pembelajaran disekolah. Dari hasil observasi tersebut dapat dilihat bahwa perilaku moral anak yang menggunakan kegiatan bercerita dengan buku cerita Islami lebih baik. Hal ini terlihat dari cara anak berperilaku dengan orang lain.

Anak yang diberikan kegiatan bercerita dengan buku cerita Islami lebih memperhatikan peraturan seperti menunjukkan perilaku disiplin, lebih mengembangkan hati nurani seperti menunjukkan perilaku membantu orang lain, perilaku berbagi dan perilaku menghargai orang lain, anak juga lebih mengetahui tindakan benar dan salah seperti anak meminta izin saat meminjam kepunyaan orang lain. Hal tersebut sesuai dengan pendapat Ormrod bahwa pada usia 3 hingga 5 tahun karakteristik moral anak yaitu : (1) anak tahu tentang kaidah sosial mengenai perilaku yang tepat, (2) anak malu dan bersalah bila melakukan pelanggaran moral, (3) meningkatnya rasa empati pada anak terhadap individu-individu yang belum dikenal, yang menderita atau berkekurangan, (4) apreasiasi terhadap kerjasama dan kompromi, dan (5) meningkatnya hasrat untuk menolong orang lain. Selain itu Wahyuning dan Rachmadiana mengungkapkan bahwa, usia 5 hingga 6 tahun anak mulai menunjukkan karakternya, mulai dapat belajar untuk berbagi, mengembangkan kepekaan akan hal yang benar dan salah, serta kepe- kaan empati dan kasih sayang.

Bercerita dengan buku cerita Islami merupakan salah satu kegiatan yang sangat efektif dalam memberikan contoh-contoh perilaku teladan kepada anak melalui tokoh-tokoh nabi. Anak-anak tertarik dengan kisah yang digambarkan dalam buku cerita Islami. Hal ini didukung oleh pendapat Syantut bahwa kisah-kisah para nabi memuat nilai-nilai akhlak yang terpuji. Seorang anak usia dini mempunyai pemikiran yang bersih, hati yang suci, dan cenderung berpihak pada hal-hal yang baik. Hal yang telah dipaparkan tersebut berdasarkan pada hasil pengujian dengan menggunakan distribusi t dapat diketahui bahwa thitung $=4,837$ serta ttabel dengan signifikansi $\alpha 0,05=$ 168. Oleh karena itu thitung $>$ ttabel maka $\mathrm{HO}$ ditolak, yang berarti menunjukkan terdapat pengaruh positif signifikan kegiatan bercerita dengan buku cerita Islami terhadap perilaku moral anak usia 5-6 tahun .

Berdasarkan hal tersebut maka dapat dinyatakan bahwa hipotesis yang telah diajukan sesuai dengan hasil penelitian. Dengan kata lain, kegiatan bercerita dengan buku cerita Islami berpengaruh terhadap perilaku moral anak usia 5-6 tahun pada anak RA kelompok $B$. Hal ini dapat dilihat dari nilai rata-rata perilaku moral anak usia 5-6 tahun pada RA kelompok $B$ yang diberikan kegiatan bercerita dengan buku cerita Islami lebih baik dari rata-rata perilaku moral anak usia 5-6 tahun pada RA kelompok B yang tidak diberikan kegiatan bercerita dengan buku cerita Islami.

\section{PENUTUP}

\section{Kesimpulan}

Berdasarkan hasil perhitungan pada pengujian hipotesis penelitian, diperoleh thitung $=4,837$ dan $t_{\text {tabel }}$ $=1,68$ pada taraf signifikansi $\alpha=0,05$ dengan $n=40$, maka $t_{\text {hitung }}$ lebih besar $t_{\text {tabel }}$ sehingga $H_{0}$ yang menyatakan bahwa tidak terdapat pengaruh yang positif signifikan kegiatan bercerita dengan buku cerita Islami terhadap perilaku moral anak usia 5-6 tahun ditolak dan $\mathrm{H}_{1}$ yang menyatakan bahwa terdapat pengaruh positif kegiatan bercerita dengan buku cerita Islami terhadap perilaku moral anak usia 5-6 tahun diterima.

Berdasarkan hasil analisis di atas, dapat disimpulkan bahwa terdapat pengaruh positif signifikan kegiatan bercerita dengan buku cerita Islami terhadap perilaku moral anak usia 5-6 tahun dibandingkan dengan anak yang tidak diberikan kegiatan bercerita dengan buku cerita Islami karena hasil uji hipotesis menyatakan bahwa terdapat pengaruh antara variabel terikat perilaku moral anak usia 5-6 tahun dengan variabel bebas kegiatan bercerita dengan buku cerita
Islami. Dengan demikian, anak yang mendapatkan kegiatan dengan buku cerita Islami, perilaku moralnya akan lebih tinggi dari pada anak yang tidak diberikan kegiatan bercerita dengan buku cerita Islami.

\section{Saran}

Saran dalam penelitian ini yaitu : (1) bagi Ketua Yayasan Pendidikan dan Kepala Sekolah diharapkan dapat menambah koleksi buku-buku cerita islami yang disesuaikan dengan usia dan perkembangan anak usia dini yang masih minim; (2) Bagi guru hendaknya dapat meningkatkan diri secara kreatif dengan memberikan suasana pembelajaran yang menarik dengan menggunakan media seperti buku cerita islami yang bergambar, boneka tangan, dvd player dengan berbagai film anak dan lain-lain, serta memberikan kegiatan seperti bercerita menggunakan buku cerita, mendongeng, menonton cerita islami bersama, dan kegiatan lainnya yang berkaitan dengan pengembangan perilaku moral agar dapat lebih disenangi dan dinikmati oleh anak, sehingga apa yang ingin disampaikan kepada 
anak dapat tercapai; dan (3) bagi orang tua hendaknya membiasakan meningkatkan pembentukan perilaku moral anak di rumah. Karena bercerita adalah salah satu kegiatan yang dapat mempengaruhi proses berfikir anak yang mudah diserap dan dipahami dalam mengaplikasikannya ke kehidupan nyata. Selain itu orang tua juga dapat mendongeng untuk anak. Orang tua dapat membacakan cerita maupun mendongeng kepada anak disaat waktu luang, seperti saat menemani anak bermain sebelum tidur.

\section{DAFTAR PUSTAKA}

Borba, M. (2008). Membangun kecerdasan moral. Jakarta: Gramedia Pustaka.

Gunarti, W., dkk. (2010). Metode pengembangan perilaku dan kemampuan dasar anak usia dini. Jakarta: Universitas Terbuka.

Handayu. T. (2001). Memaknai cerita mengasah jiwa. Solo: Era Intermedia.

Hurlock, E. (1999). Perkembangan anak jilid 2. Jakarta: Erlangga.

Mal, Kak (2009). The power of story telling. Depok: Metro Media.

Moeslichatoen. (2004). Metode pengajaran di taman kanak-kanak. Jakarta: Rineka Cipta.

Moshos, F., \& Scoott, N. C. (2005). Teaching good behavior. China: Time Life Inc.

Musfiroh, T. (2008). Memilih, menyusun dan menyajikan cerita untuk anak usia dini. Yogyakarta:
Tiara Wacana.

Sjarkawi. (2006). Pembentukkan kepribadian anak. Jakarta: Sinar Grafika Offset.

Suyatno, T. (2011). Pengaruh pornografi terhadap perilaku belajar siswa. Jurnal Pendidikan Dompet Dhuafa edisi I.

Syantut, K.A.A. (2005). Rumah pilar utama pendidikan anak. Jakarta: Robbani Perss.

UNESCO. (2000). Behavior modification. Diakses dari situs unesco.org, hal. http://www.unesco.org/ education/mebam/module_4.pdf.

Wahyudi \& Damayanti. (2005). Program pendidikan untuk anak usia dini di prasekolah Islam. Jakarta: Grasindo.

Waston, J. B. (1999). Teori Psikologi Sosial. Jakarta: Gunung Mulia. 